mology, held in Montreal and New York-a huge gathering of 3,000 delegates with continuous sets of meetings running in parallel and necessarily strictly limited discussion. Although this provided an excellent opportunity for colleagues all over the world to meet each other, there was no question whatever that the scientific value of one half day at the symposium was greater than that of the whole eight days of the Congress. The C.I.O.M.S. and its two sponsoring bodies, UNESCO and WHO, are indeed to be congratulated on the conception and organization of meetings of this type which probably do more for the advancement of medicine than any other type of conference.

Those taking part were: Ashton (London); Bárány (Uppsala); Berens (New York); Duke-Elder (London, Chairman); Elliot (Toronto); François (Ghent); Friedenwald (Baltimore); Goldmann (Berne); Grant (Boston); Hartmann (Paris); Hodgson (Toronto, Secretary); Kinsey (Detroit); Kronfeld (Chicago); Langham (London); Leydhecker (Bonn); Malbran (Buenos Aires); Scheie (Philadelphia); Sourdille (Nantes); Vail (Chicago); Weekers (Liége).

Sir Stewart Duke-Elder.

\title{
NOTES
}

\section{INTERNATIONAL COUNCIL OF OPHTHALMOLOGY AND INTERNATIONAL FEDERATION OF OPHTHALMOLOGICAL SOCIETIES}

Résumé of the minutes of the meetings held at the XVII International Congress of Ophthalmology at Montreal in September, 1954

\section{INTERNATIONAL COUNCIL OF OPHTHALMOLOGY}

Apart from current business, the following is a summary of the main decisions taken:

(1) International Standardizations.-The main business of the meeting concerned the international standardization of visual requirements for transport workers. The reports of the committees dealing with the standardization of optotypes, the colour sense, and the limits of spectacle correction recommended for transport workers were considered and referred to the International Federation for confirmation. A scheme for the codification of the colours of labels of ophthalmic drugs was also agreed. These recommendations will be noted in the Minutes of the Federation.

(2) Ophthalmological Education.-The Council considered the report presented by Alvaro on behalf of the committee which had been studying the question of ophthalmological education. This was thought to be of such importance that it was decided to submit it to the principal ophthalmic journals in the world for publication.

(3) International Dictionary of Ophthalmic Terms.-The committee concerned reported on the progress of the "International Dictionary of Ophthalmic Terms"; it is hoped that this dictionary, which contains such terms in six languages (English, French, German, Italian, Latin, and Spanish) will appear in the near future. 
(4) Index Ophthalmologicus.-The publication of the new Index Ophthalmologicus was considered; the Council thanked Dr. A. C. Copper for his excellent work in its preparation. This new Index contains a résumé of the Council's activities, and a list of the names and addresses of ophthalmologists in most countries of the world, as well as particulars of the ophthalmic hospitals, societies for the blind, ophthalmological societies, and ophthalmic journals. The Index can be obtained from Dr. A. C. Copper, 97 Nieuwstad, Zutphen, Holland, for the sum of $2 \cdot 75$ dollars, $£ 1$ sterling, or their equivalent.

(5) Affiliation of new Societies.-The Council approved requests for affiliation from the ophthalmological societies of Australia, Colombia, India, and Venezuela.

(6) XVIII International Congress.-Recommendations were made to the Federation regarding the next International Congress, and the next meeting of the Council was fixed to take place in Paris, on May 7, 1955.

\section{INTERNATIONAL FEDERATION OF OPhTHALMOLOGICAL SOCIETIES}

The main business was as follows:

(1) New Statutes. - The new Statutes regulating the activities of the International Council, the International Federation, and International Congresses were studied and, with minor amendments, were provisionally accepted until their final consideration in 1958. According to these statutes, every endeavour is to be made to keep national delegates (and, through them, their societies) acquainted with the work of the International Council.

(2) Subscriptions.-The annual subscription for member societies to the Federation was retained without modification, that is, at the rate of one-half Swiss franc per member.

(3) International Standardizations. - The recommendations of the Council on international standardization in examining candidates for employment on public transport were considered, as well as the Council's recommendations on the labelling of ophthalmic drugs. The essential recommendations are shown in an appendix (below).

(4) XVIII International Congress of Ophthalmology.-It was decided that the next Congress should be held in September, 1958, in Brussels, with Professor Léon Coppez as President; this country was chosen as a compliment to the Belgians in view of the fact that this would be a centenary meeting, the first Congress having been held in Belgium in 1857.

(5) New International Council.-The new International Council was elected as follows:

President of the Council (and of the Federation)-Duke-Elder (Great Britain).

Vice-President of the Council (and of the Federation)-Berens (United States).

Secretary of the Council (and of the Federation)-Hartmann (France).

Treasurer of the Council (and of the Federation)-Amsler (Switzerland).

President International Association for the Prevention of Blindness-Franceschetti (Switzerland).

President International Organization against Trachoma-Bietti (Italy).

President Pan-American Association of Ophthalmology - to be appointed in 1956.

Retiring President of the Congress-Samuels (United States).

President of the next Congress-Coppez (Belgium).

Ordinary members: Alvaro (Brasil); Arruga (Spain); Charamis (Greece); Palomino Dena (Mexico); Duggan (India); Lyle (Great Britain); Marshall (Canada); Paufique (France); Thiel (Germany); Weve (Holland). 


\section{APPENDIX}

(1) Tables for the Transcription of the Acuity of Vision from the Decimal System

For some decimals the distance at the examination has to be altered from 6 to $5 \mathrm{~m}$. or from 20 to $15 \mathrm{ft}$.

\begin{tabular}{|c|c|c|c|}
\hline \multicolumn{4}{|c|}{ Snellen's 6-metre Tables } \\
\hline $\begin{array}{l}1 \cdot Q \\
0.8 \\
0.7 \\
0.6\end{array}$ & $\begin{array}{l}6 / 6 \\
5 / 6 \\
6 / 9 \\
5 / 9\end{array}$ & $\begin{array}{l}0.5 \\
0.4 \\
0.3 \\
0.1\end{array}$ & $\begin{array}{l}6 / 12 \\
5 / 12 \\
6 / 18 \\
6 / 60\end{array}$ \\
\hline \multicolumn{4}{|c|}{ 20-foot Tables } \\
\hline $\begin{array}{l}1.0 \\
0.8 \\
0.7 \\
0.6\end{array}$ & $\begin{array}{l}20 / 20 \\
20 / 25 \\
20 / 30 \\
15 / 25\end{array}$ & $\begin{array}{l}0.5 \\
0.4 \\
0.3 \\
0.1\end{array}$ & $\begin{array}{l}20 / 40 \\
20 / 50 \\
20 / 70 \\
20 / 200\end{array}$ \\
\hline \multicolumn{4}{|c|}{ Resolution Angle Tables } \\
\hline $\begin{array}{l}1.0 \\
0.9 \\
0.8 \\
0.7 \\
0.6\end{array}$ & $\begin{array}{l}1 \cdot 0 \\
1 \cdot 1 \\
1 \cdot 3 \\
1 \cdot 4 \\
1 \cdot 6\end{array}$ & $\begin{array}{l}0.5 \\
0.4 \\
0 \cdot 3 \\
0 \cdot 2 \\
0 \cdot 1\end{array}$ & $\begin{array}{r}2 \cdot 0 \\
2 \cdot 5 \\
3 \cdot 3 \\
5 \cdot 0 \\
10 \cdot 0\end{array}$ \\
\hline
\end{tabular}

\section{(2) Colour Sense}

The colour sense will be tested by isochromatic tables. At present the Ishihara tables are recommended. Others which may be found to be equally good or better may also be recommended in the future.

\section{(3) TONOMETRY}

The Schiötz tonometer is recommended as conforming to the specifications of the Committee on Standardization of Tonometers of the American Academy.

(4) Recommendations for the Spectacles allowable for Candidates for Employment in Public Transport

$\begin{array}{ll}\text { Concave spherical lenses } & 7 \mathrm{D} \text { maximum } \\ \text { Convex spherical lenses } & +4 \mathrm{D} \text { maximum } \\ \text { Cylindrical lenses } & \pm 4 \mathrm{D} \text { maximum } \\ \text { Unshatterable lenses advisable } & \\ \text { Periscopic lenses advisable } & \\ \text { Tinted lenses advisable only in bright daylight } \\ \text { Stability of the mounting of spectacles important } \\ \text { The provision of a second pair of spectacles as replacements advisable } \\ \text { Contact lenses acceptable if previously tolerated for } 3 \text { months }\end{array}$

\section{(5) Labelling of Ophthalmic Drugs}

It is recommended that the labels of ophthalmic medications should be of different colours depending on their nature as follows:

(a) Red.-Drugs that in certain circumstances can be dangerous, e.g., mydriatics.

(b) Orange.-Drugs to be used with caution, e.g., miotics, cortisone, priscol, adrenaline, antibiotics, etc.

(c) Green.-Drugs without danger, e.g., colloidal silver preparations, zinc sulphate, mild antiseptics, antistine, privine, etc.

(d) Red with Green Bands.-Anaesthetics. 


\section{Ophthalmological Society of The UNITED Kingdom}

Annual Congress, 1955

The Annual Congress will be held at the Royal Society of Medicine, 1, Wimpole Street, London, W.1., on April 28, 29, and 30, 1955. The presidential address will be delivered by Mr. O. Gayer Morgan on "Some Aspects of Thrombosis of the Retinal Veins and its Treatment". A discussion on "Sarcoidosis" will be opened by Dr. J. G. Scadding, Mr. A. G. Cross, and Mr. R. P. Crick. There will also be short symposia on "Diamox in the Treatment of Glaucoma", "Relaxant Drugs and Anaesthesia in Ophthalmic Surgery", and "The Use of Air in Ophthalmology".

The Bowman Lecture will be delivered by Dr. John H. Dunnington on "Ocular Wound Healing".

Members wishing to read papers, give demonstrations, or show films are asked to communicate with, Mr. Ainslie not later than December 31, 1954.

The Annual Dinner, to which members may bring guests, will be held on April 28. A Trade Exhibition will be held in the Cowdray Hall (next door to the Royal Society of Medicine). All members who will require hotel accommodation are advised to make their arrangements in good time.

$$
\text { Honorary Secretaries }\left\{\begin{array}{l}
\text { Arthur Lister (Council Business). } \\
\text { Derek Ainslie (Congress Business). }
\end{array}\right.
$$

\section{HoNOURS}

At a Convocation at McGill University, Montreal, on October 6, 1954, the honorary degree of Doctor of Science was conferred on Sir Stewart Duke-Elder.

Mr. B. W. Rycroft has been made an honorary member of the Ophthalmological Society of South Africa.

\section{OBITUARY}

\section{LeGrand H. HaRdy}

Dr. LeGrand H. Hardy died on April 14, 1954, at the age of 59. He was a well-known and well-liked American ophthalmologist, Clinical Professor of Ophthalmology in the College of Physicians and Surgeons at Columbia University, and Director of the Knapp Memorial Physiological Optics Laboratories at the Presbyterian Hospital of New York. His main interest lay in the field of physiological optics in which he was recognized as a world authority.

\section{WALTER LÖHLEIN}

WE have heard with great regret of the recent death of Professor WALTER LöHLEN of Berlin, one of the foremost German ophthalmologists of his day, and until recently a member of the International Council of Ophthalmology. 